\section{Special Issue: Altmetrics}

\section{Editorial}

Scholarly and Research

Communication

VOLUME 10 / ISSUE 1 / 2019

Rowland Lorimer is Editor of Scholarly Research and Communication. Email: lorimer@sfu.ca.

Monique Sherrett is founder of Boxcar Marketing. Email: lbcollister@pitt.edu
CISP Press

Scholarly and Research Communication

Volume 10, Issue 1, Article ID 1006339, 2 pages

Journal URL: www.src-online.ca http://doi.org/10.22230/src.2019v10n1a339

Received January 14, 2019, Accepted January 14, 2019, Published January 31, 2019

Lorimer, Rowland \& Sherrett, Monique. (2019). Editorial. Special Issue: Altmetrics. Scholarly and Research Communication, 10(1): 1006339, 2 pp.

(C) 2019 Rowland Lorimer \& Monique Sherrett. This Open Access article is distributed under the terms of the Creative Commons Attribution Non-Commercial License (http://creativecommons.org /licenses/by-nc-nd/2.5/ca), which permits unrestricted non-commercial use, distribution, and reproduction in any medium, provided the original work is properly cited. 
Scholarly and Research

\section{Communication}

VOLUME 10 / ISSUE 1 / 2019 and the contribution an article makes to discourse in the field. It reveals, by means of some telling examples, how archivists have increased the interactions of users with archives by contributing to ongoing conversations that touch on their collections. It is well worth a read.

Rowland Lorimer, Editor, SRC

Monique Sherrett, Boxcar Marketing 